\title{
PERLINDUNGAN HUKUM TERHADAP EKSPLOITASI ANAK YANG BERPROFESI ARTIS BERDASARKAN UNDANG-UNDANG NOMOR 35 TAHUN 2014
}

oleh:

\author{
Anton Fujiana \\ Meima
}

\begin{abstract}
ABSTRAK
Anak merupakan generasi penerus bangsa dan penerus perjuangan pembangunan yang ada. Anak adalah amanah sekaligus karunia Tuhan Yang Maha Esa yang senantiasa harus kita jaga karena dalam dirinya melekat harkat, martabat dan hak-hak sebagai manusia yang harus dijunjung tinggi. Kehadiran pekerja anak di Indonesia bukan hal yang baru, banyak anak yang menjadi korban eksploitasi ekonomi maupun seksual karena adanya faktor pendorong yang mengharuskan anak melakukan pekerjaan. Begitu juga dengan anak yang berprofesi sebagai artis atau sering disebut artis cilik. Mempekerjakan anak tanpa memperhatikan hak-hak anak merupakan suatu hal yang melanggar hak asasi anak, karena eksploitasi pekerja anak selalu berdampak buruk terhadap perkembangan anak baik secara fisik, mental dan sosial anak. Berdasarkan hal tersebut, maka permasalahan dalam penelitian ini adalah Bagaimana Perlindungan Hukum Terhadap Eksploitasi Anak yang Berprofesi Artis Berdasarkan Undang-Undang Nomor 35 Tahun 2014 Tentang Perubahan Atas UndangUndang Nomor 23 Tahun 2002 Tentang Perlindungan Anak Juncto Undang-Undang Nomor 13 Tahun 2003 Tentang Ketenagakerjaan serta Bagaimana Upaya Penanggulangan Pemerintah Terhadap Anak Profesi Artis Dari Tindakan Eksploitasi. Anak berprofesi artis sangat rentan terhadap praktik eksploitasi, maka anak berprofesi artis berhak dan harus dilindungi dari praktek kekerasan dan/atau dari bentuk eksploitasi, perlindungan hukum terhadap anak dengan memberi anak kesempatan yang seluas-luasnya untuk tumbuh, dan berkembang secara optimal, baik fisik, mental, sosial. Anak mempunyai hak untuk berisitirahat dan memanfaatkan waktu luang, bergaul dengan anak sebaya, berrekreasi berkreasi sesuai dengan minat, bakat dan tingkat kecerdasannya demi pengembangan diri. Pemerintah dalam hal upaya menaggulangi permasalahan anak melalui dinas terkait dimulai dari daerah-daerah melakukan pengawasan secara baik dan berlanjut, kemudian pemberian sanksi terhadap pelaku terkait harus lebih tegas. Pelibatan berbagai instansi pemerintah, perusahaan, serikat pekerja, lembaga swadaya masyarakat dan juga masyarakat dalam upaya menaggulangi tindakan eksploitasi terhadap anak secara ekonomi dan/atau seksual.
\end{abstract}

\section{PENDAHULUAN}

\section{Latar Belakang}

Anak merupakan generasi penerus bangsa dan penerus perjuangan pembangunan yang ada. Anak adalah amanah sekaligus karunia Tuhan Yang Maha Esa yang senantiasa harus kita jaga karena dalam dirinya melekat harkat, martabat dan hak-hak sebagai manusia yang harus dijunjung tinggi. Hak asasi anak merupakan bagian dari hak asasi manusia yang termuat dalam Undang-Undang Dasar 1945 dan Konvensi Perserikatan Bangsa-Bangsa tentang HakHak Anak. Dari sisi kehidupan berbangsa dan bernegara, anak adalah masa depan bangsa dan generasi penerus cita-cita bangsa, sehingga setiap anak berhak atas kelangsungan hidup, tumbuh, dan berkembang, berpartisipasi serta berhak atas perlindungan dari tindak kekerasan dan diskriminasi serta hak sipil dan kebebasan.

Kehadiran pekerja anak di Indonesia bukan hal yang baru. Begitupun dengan keberadaan pekerja anak berprofesi sebagai artis atau sering disebut artis cilik. Banyak anak yang menjadi korban eksploitasi ekonomi maupun seksual karena adanya faktor pendorong yang menyebabkan seorang anak diharuskan untuk melakuakan pekerjaan. Pekerja anak sendiri merupakan suatu kegiatan yang dilakukan oleh anak dibawah umur 
untuk memenuhi kebutuhan hidup dirinya. maupun keluarganya. Pekerja anak sebagai artis cilik sering kali dijadikan alasan untuk mengembangkan minat dan bakatnya dan diharapkan anak dibawah umur yang berprofesi sebagai artis cilik ini dapat menghasilkan Sumber Daya Manusia (SDM) yang berkualitas. Akan tetapi hal ini lah yang akan berpotensi terjadinya tindakan eksploitasi terhadap anak yang berprofesi artis.

Mempekerjakan anak tanpa memperhatikan hal-hak anak untuk tumbuh dan berkembang secara optimal baik dari segi fisik, mental dan sosial anak tersebut pada dasarnya merupakan suatu hal yang melanggar hak asasi anak, karena eksploitasi pekerja anak selalu berdampak buruk terhadap perkembangan anak baik secara fisik, mental dan sosial anak tersebut. Mempekerjakan anak memang tidak diperbolehkan, ketentuan ini tercantum dalam Pasal 68 Undang-Undang Nomor 13 Tahun 2003 tentang Ketenagakerjaan yang berbunyi Pengusaha dilarang memperkerjakan anak. Akan tetapi apabila dalam keadaan memaksa karena faktor ekonomi maupun untuk mengembangkan minat dan bakat, anak boleh bekerja asalkan tidak boleh menyimpang dari ketentuan dalam Undang-Undang yang diatur dalam Undang-Undang Nomor 13 Tahun 2003 tentang Ketenagakerjaan. Dalam ketentuan Pasal 69 ayat (1) Undang-Undang Nomor 13 Tahun 2003 tentang Ketenagakerjaan menyebutkan bahwa Ketentuan sebagaimana dimaksud dalam pasal 68 dapat dikecualikan bagi anak yang berumur antara 13 (tiga belas) tahun sampai dengan 15 (lima belas) tahun untuk melakukan pekerjaan ringan sepanjang tidak mengganggu perkembangan dan kesehatan fisik, mental dan sosial. Kemudian dalam Pasal 69 ayat (2) menyebutkan bahwa pengusaha yang mempekerjakan anak pada pekerjaan ringan sebagaimana dimaksud dalam ayat (1) harus memenuhi persyaratan yaitu izin tertulis dari orang tua atau wali, perjanjian kerja antara pengusaha dengan orang tua atau wali, waktu kerja maksimum 3 (tiga) jam, dilakukan pada siang hari dan tidak mengganggu waktu sekolah, keselamatan dan kesehatan kerja, adanya hubungan kerja yang jelas dan menerima upah sesuai dengan ketentuan yang berlaku.

Semua peraturan di atas pada kenyataannya sangat berlawanan dengan kondisi yang ada saat ini, pelaku industri televisi dan orang tua sering tidak menyadari telah melakukan eksploitasi terhadap anak. Karena banyak juga dari anak-anak yang masih berumur dibawah 13 (tiga belas) tahun melakukan pekerjaan dengan alasan sebagai pengembangan minat dan bakat dengan waktu kerja yang sangat padat yaitu lebih dari 3 (tiga) jam sehari, untuk artis cilik yang bekerja sebagai pemain sinetron sehingga mengganggu waktu sekolah, fisik, mental, dan sosial artis cilik tersebut. Bahkan tidak sedikit artis cilik yang berhenti sekolah dan memilih untuk Home Schooling.

Tindakan tersebut dapat dikatakan sebagai bentuk eksploitasi terhadap anak dan dapat menimbulkan sanksi pidana sebagaimana telah diatur dalam pasal 88 Undang-Undang Nomor 23 Tahun 2002 Tentang Perlindungan Anak Juncto Undang-Undang Nomor 35 Tahun 2014 yang berbunyi Setiap orang yang mengeksploitasi ekonomi atau seksual anak untuk menguntungkan diri sendiri atau orang lain, dipidana dengan pidana penjara paling lama 10 (sepuluh) tahun dan/atau denda paling banyak Rp 200.000.000,00 (dua ratus juta rupiah).

Seperti Contoh kasus I : anak yang berperan sebagai artis cilik Misca Fortuna, pemeran si mancung dalam sinetron Emak Ijah Pengen Ke Mekah ini mengalami perlakuan dari Muhammad Delsy yang merupakan ayah kandung nya sendiri. Uang tabungan hasil jerih payah Misca Fortuna bermain sinetron dipergunakan Delsy tanpa sepengetahuan Misca dan ibu kandung Misca, uang sejumlah sekitar Rp 100.000.000,00 (seratus juta rupiah) dibawa kabur ayah Misca. uang tersebut diambil dan dipergunakan untuk bermain judi online.

Contoh kasus II : Tegar Septian seorang penyanyi cilik mendapat perlakuan yang tidak senonoh dari manager, Tegar sering diperlakukan dengan sewenang-wenang, Tegar harus menuruti semua keinginan yang diminta oleh manager, selain diharuskan untuk manggung kesana kesini Tegar juga diharuskan melayani nafsu manager nya itu. Tegar harus menuruti keinginan salah satu nya ketika tidur harus satu kamar, tidak boleh memakai celana, mandi berdua dan yang paling bahaya manager Tegar rupanya juga kerap menempelkan alat vital untuk menggoda Tegar. Diketahui bahwa manager Tegar ini adalah seorang yang homo, 
juga pedofil atau penyimpangan seksual terhadap anak kecil. dan selalu berupaya untuk melakukan sodomi kepada Tegar.

\section{Identifikasi Masalah}

1.....Bagaimana Perlindungan Hukum Terhadap Eksploitasi Anak yang Berprofesi Artis Berdasarkan Undang-Undang Nomor 35 Tahun 2014 Tentang Perubahan Atas UndangUndang Nomor 23 Tahun 2002 Tentang Perlindungan Anak Juncto Undang-Undang Nomor 13 Tahun 2003 Tentang Ketenagakerjaan?

2. Bagaimana Upaya Penanggulangan Pemerintah Terhadap Anak Profesi Artis Dari Tindakan Eksploitasi?

\section{TINJAUAN PUSTAKA}

\section{Perlindungan Anak}

Anak merupakan karunia dari Tuhan Yang Maha Esa yang harus dijaga karena dalam dirinya melekat harkat, martabat dan hak-hak sebagai manusia yang harus dijunjung tinggi. Anak adalah bagian yang tidak terpisahkan dari keberlangsungan hidup manusia dan keberlangsungan sebuah bangsa dan Negara. Dalam Konsitusi Indonesia, anak memiliki peran strategis yang secara tegas dinyatakan bahwa Negara menjamin hak setiap anak atas kelangsungan hidupnya, tubuh dan berkembang serta atas perlindungan dari kekerasan dan diskriminasi.

Anak merupakan seseorang yang dilahirkan dari sebuah hubungan antara pria dan wanita. Hubungan pria dan wanita ini jika terikat dalam suatu ikatan perkawinan lazimnya disebut sebagai suami istri. ${ }^{1)}$ Dapat diartikan bahwa anak merupakan hasil dari perkawinan sepasang suami istri.

Terdapat beberapa pengertian menurut peraturan Perundang-undangan begitu juga menurut para ahli, namun tidak ada keseragaman mengenai pengertian anak tersebut. Pengertian anak sangat luas, anak dikategorikan menjadi beberapa kelompok usia ,yaitu masa anak-anak berumur 0-12 (nol-dua belas) tahun, masa remaja berumur 13-20 (tiga belas-dua puluh) tahun, dan masa dewasa berumur 21-25 (dua puluh satu-dua puluh lima) tahun. Secara umum kita ketahui yang dimaksud dengan anak yaitu orang yang masih belum dewasa atau masih belum kawin.

Beberapa pengertian anak menurut Undang-Undang Nomor 3 Tahun 1997 Tentang Pengadilan Anak, Undang-Undang Nomor 23 Tahun 2002 Tentang Perlindungan Anak, dan Undang-Undang Nomor 11 Tahun 2012 Tentang Sistem Peradilan Pidana Anak, Menurut Undang-Undang Nomor 13 Tahun 2003 Tentang Ketenagakerjaan, Menurut Undang-Undang Nomor 39 Tahun 1999 Tentang Hak Asasi Manusia dan juga Menurut Beberapa Ahli.

Menurut Pasal 1 ayat (1) dan (2) Undang-Undang Nomor 3 Tahun 1997 Tentang Pengadilan Anak, menyatakan:

a) Anak adalah orang yang dalam perkara Anak Nakal telah mencapai umur 8 (delapan) tahun tetapi belum mencapai umur 18 (delapan belas) tahun dan belum pernah kawin.

b) Anak Nakal adalah:

a. Anak yang melakukan tindak pidana, atau

b. Anak yang melakukan perbuatan yang dinyatakan terlarang bagi anak, baik menurut peraturan perundang-undangan maupun menurut peraturan hukum lain yang hidup dan berlaku dalam masyarakat yang berangkutan.

Mengenai batasan usia di atas, telah dirubah oleh Putusan Mahkamah Konsitusi Nomor.1/PUU/-VIII/2010, dari 8 (delapan) tahun menjadi 12 (dua belas) tahun. Jadi Menurut Putusan Mahkamah Konstitusi ini, bahwa orang yang telah berumur 18 (delapan belas) tahun

1) Abu Huraerah, Kekerasan Terhadap Anak, Nuansa, Bandung 2006, Hlm. 36 
keatas pada waktu 18 (delapan belas) tahun melakukan tindak pidana maka tuntutan yang diberlakukan sama dengan tuntutan terhadap orang dewasa.

Menurut Pasal 1 angka 1 Undang-Undang Nomor 23 Tahun 2002 Tentang Perlindungan Anak, menyatakan: Anak adalah seorang yang belum berusia 18 (delapan belas) tahun termasuk anak yang masih dalam kandungan.

Menurut Pasal 1 angka 3 Undang-Undang Nomor 11 Tahun 2012 Tentang Sistem Peradilan Pidana Anak, menyatakan:

Anak adalah anak yang telah berumur 12 (dua belas) tahun, tetapi belum berumur 18 (delapan belas) tahun yang diduga melakukan tindak pidana.

Menurut Undang-Undang Nomor 13 Tahun 2003 Tentang ketenagakerjaan bahwa yang di sebut anak adalah setiap orang yang belum berusia 18 (delapan belas) tahun.

Menurut Undang-Undang Nomor 39 Tahun 1999 Tentang Hak Asasi Manusia dalam Pasal 1 sub 5 dinyatakan bahwa Anak adalah tiap manusia yang berusia dibawah 18 (delapan belas) tahun dan belum menikah, termasuk anak yang masih dalam kandungan.

Menurut R.A. Kosnan Anak-anak yaitu manusia muda dalam umur muda dalam jiwa dan perjalanan hidupnya karena mudah terpengaruh untuk keadaan sekitarnya. ${ }^{2)}$

Menurut Nur Hasyim yang dimaksud dengan anak adalah seseorang yang belum berusia 18 tahun termasuk yang masih dalam kandungan ibunya, yang merupakan amanah dan karunia Tuhan Yang Maha Esa, memiliki harkat, martabat serta hak-hak sebagai manusia yang harus dihormati. ${ }^{3)}$

Dari beberapa pengertian diatas, dapat ditarik kesimpulan bahwa seseorang di kategorikan sebagai anak atau belum dewasa adalah anak yang telah berumur 12 (dua belas) tahun tetapi belum berumur 18 (delapan belas) tahun. Dalam Undang-undang ini tidak menyebutkan anak tersebut sudah atau belum kawin, sehingga apabila anak terikat dalam suatu perkawinan atau perkawinanya putus karena penceraianya, anak tersebut dianggap sudah dewasa meskipun umurnya belum 18 (delapan belas) tahun. Dari pengertian anak menurut para ahli dan Undang-Undang memberikan pandangan yang berbeda-beda dan tidak keseragaman dalam menentukan bagaimanakah dapat dikatakan anak, menurut masingmasing dalam mengatakan setiap perbedaan pemahaman tersebut sesuai apa yang diperlukan didalamnya dan sudah disesuaikan dengan perkembangan kebutuhan masyarakat.

\section{Perlindungan Hukum Terhadap Anak}

Perlindungan hukum adalah memberikan pengayoman kepada hak asasi manusia yang dirugikan orang lain dan perlindungan tersebut diberikan kepada masyarakat agar mereka dapat menikmati semua hak-hak yang diberikan oleh hukum atau dengan kata lain perlindungan hukum adalah berbagai upaya hukum yang harus diberikan oleh aparat penegak hukum untuk memberikan rasa aman, baik secara pikiran maupun fisik dari gangguan dan berbagai ancaman dari pihak manapun. Perlindungan hukum merupakan gambaran dari bekerjanya fungsi hukum dalam mewujudkan tujuan-tujuan hukum yakni keadilan kemanfaatan dan kepastian hukum. Perlindungan hukum ini diberikan kepada subjek hukum sesuai dengan aturan hukum, baik itu bersifat preventif maupun dalam bentuk yang bersifat represif dalam rangka penegakan hukum. Dasar Hukum Perlindungan Anak Undang-Undang Republik Indonesia Nomor 35 Tahun 2014 tentang Perubahan Atas Undang-Undang Nomor 23 Tahun 2002 Tentang Perlindungan Anak.

Pengertian Perlindungan Anak dapat ditemui pada Pasal 1 angka 2 Undang-Undang Republik Indonesia Nomor 35 tahun 2014 Tentang Perubahan Atas Undang-Undang Nomor 23 Tahun 2002 Tentang Perlindungan Anak berbunyi :

"Perlindungan anak adalah segala kegiatan untuk menjamin dan melindungi anak dan hakhaknya agar dapat hidup, tumbuh, berkembang,dan berpartisipasi secara optimal sesuai

${ }^{2)}$ R.A. Koesnan, Susunan Pidana dalam Negara Sosialis Indonesia, (Bandung :Sumur, 2005), op.cit. hlm. 113

${ }^{3)} \mathrm{http}$ //free.makalah.blogspot.com/2010/07perlindungan-anak-menurut-uu-no.html?m=1 
dengan harkat dan martabat kemanusiaan, serta mendapat perlindungan dari kekerasan dan diskriminasi".

Anak adalah amanah sekaligus karunia Tuhan Yang Maha Esa yang senantiasa harus kita jaga karena dalam dirinya melekat harkat, dan martabat dan hak-hak sebagai manusia yang harus dijunjung tinggi. Hak asasi anak merupakan bagian dari hak asasi manusia yang termuat dalam Undang-Undang Dasar 1945 dan Konvensi Perserikatan Bangsa-Bangsa tentang hak-hak Anak. Dari sisi kehidupan berbangsa dan bernegara, anak adalah masa depan bangsa dan generasi penerus cita-cita bangsa sehingga setiap anak berhak atas kelangsungan hidup, tumbuh, dan berkembang, berpartisipasi serta berhak atas perlindungan dari tindak kekerasan dan diskriminasi serta hak sipil dan kebebasan. Meskipun Undang-Undang No 39 Tahun 1999 Tentang Hak Asasi Manusia telah mencantumkan tentang hak anak, pelaksanaan kewajiban dan tanggungjawab orang tua,keluarga, masyarakat, pemerintah, dan negara untuk memberikan perlindungan pada anak masih memerlukan suatu undang-undang mengenai perlindungan anak sebagai landasan yuridis bagi pelaksanaan kewajiban dan tanggungjawab tersebut.

Dengan demikian, pembentukan Undang-Undang didasarkan pada pertimbangan bahwa perlindungan anak dalam segala aspeknya merupakan bagian dari kegiatan pembangunan nasional, khususnya dalam memajukan kehidupan dalam berbangsa dan bernegara. Orang tua, keluarga, dan masyarkat bertanggungjawab untuk menjaga dan memelihara hak asasi tersebut sesuai dengan kewajiban yang telah diatur oleh hukum.

Dalam rangka penyelenggaraan perlindungan anak, terutama dalam menjamin pertumbuhan dan perkembangannya secara optimal dan terarah. Peraturan Perundangundangan menegaskan bahwa pertanggungjawaban orang tua, keluarga, masyarakat, pemerintah dan negara merupakan rangkaian kegiatan yang dilaksanakan secara terusmenerus demi terlindunginya hak-hak anak. Rangkaian kegiatan tersebut harus berkelanjutan dan terarah guna menjamin pertumbuhan dan perkembangan anak, baik fisik, mental, spritual maupun sosial. Tindakan ini dimaksudkan untuk mewujudkan kehidupan terbaik bagi anak yang diharapakan sebagai penerus bangsa yang potensial, tangguh, memiliki nasionalisme yang dijiwai oleh akhlak mulia dan nilai pancasila, serta berkemauan keras menjaga kesatuan dan persatuan bangsa dan negara.

Upaya perlindungan anak perlu dilaksanakan sedini mungkin, yakni sejak dari janin dalam kandungan sampai anak berumur 18 (delapan belas) tahun. Bertitik tolak dari konsepsi perlindungan anak yang utuh, menyeluruh, dan komprehensif, undang-undang ini meletakkan kewajiban memberikan perlindungan kepada anak berdasarkan asas-asas berikut:

a. Nondiskriminasi

b. Kepentingan yang terbaik bagi anak

c. Hak untuk hidup, kelangsungan hidup, dan perkembangan; dan

d. Penghargaan terhadap pendapat anak.

Upaya-upaya yang dapat dilakukan untuk memberikan perlindungan hukum bagi hakhak anak dapat dilakukan dengan cara yakni :

Pertama : Perlindungan, muncul berdasarkan pandangan bahwa anak sebagai individu mempunyai hak untuk bekerja. Oleh karenanya hak-haknya sebagai pekerja harus dijamin melalui peraturan perlindungan anak sebagaimana yang berlaku bagi pekerja dewasa, sehingga terhindar dari tindak penyalahgunaan dan eksploitasi. Karena bekerja adalah bagian dari hak asasi anak yang paling dasar, meskipun masih anak-anak hukum harus dapat menjamin terwujudnya hak anak yang paling asasi untuk mendapatkan pekerjaan dan oleh karenanya juga mendapatkan penghidupan yang layak bagi kemanusiaan. Masa depan anak tidak lagi ditentukan oleh kekuatan orang tua, keluarga, masyarakat, apalagi negara. Tetapi sebaliknya orang tua, keluarga, masyarakat dan negara, mempunyai kewajiban untuk 
menjamin terwujudnya hak anak yang paling asasi yakni mendapatkan pekerjaan dan penghidupan yang layak bagi kemanusiaan.

Anak yang tereksploitasi secara ekonomi dan seksual mendapatkan perlindungan khusus oleh pemerintah dan masyarakat yang dilakukan melalui :

1. Penyebarluasan dan/atau sosialisasi ketentuan peraturan perundang-undangan yang berkaitan dengan perlindungan anak yang dieksploitasi secara ekonomi dan/atau seksual.

2. Pemantauan, pelaporan, dan pemberian sanksi.

3. Pelibatan berbagai instansi pemerintah, perusahaan, serikat pekerja, lembaga swadaya masyarakat dan juga masyarakat dalam penghapusan eksploitasi terhadap anak secara ekonomi dan/atau seksual.

Kedua : Pemberdayaan, dilakukan terhadap pekerja anak agar mendapatkan pengakuan terhadap hak-haknya dengan memberikan keterampilan sesuai dengan kebutuhannya. Selain memperhatikan hal-hal tersebut diatas, upaya memberikan perlindungan dan pencegahan terhadap pekerja anak dapat dilakukan dengan cara:

1. Mengubah persepsi masyarakat terhadap pekerja anak, bahwa anak yang bekerja dan terganggu tumbuh kembangnya dan tersita hak-haknya akan pendidikan tidak dapat dibenarkan.

2. Melakukan penyadaran atau rasionalisasi secara bertahap untuk mengeliminasi pekerja anak, khususnya diberikan kepada jenis pekerjaan yang sangat membahayakan

3. Mengundangkan dan melaksanakan peraturan perundang-undangan yang selaras dengan konvensi internasional, khususnya Konvensi Hak Anak dan Konvensi ILO lain yang menyangkut anak

4. Mengupayakan perlindungan hukum dan menyediakan pelayanan yang memadai bagi anak-anak yang bekerja di sektor informal.

5. Memastikan agar anak-anak yang bekerja memperoleh pendidikan dasar 9 tahun, pendidikan keterampilan melalui bentuk-bentuk pendidikan alternatif yang sesuai dengan kebutuhan mereka. ${ }^{4)}$

Kebijaksanaan, usaha, dan kegiatan yang menjamin terwujudnya perlindungan anak, pertama didasarkan atas pertimbangan bahwa anak merupakan golongan yang rawan, disamping itu karena adanya golongan anak-anak yang mengalami hambatan dalam pertumbuhan dan perkembangannya, baik rohani,jasmani maupun sosial. Perlindungan terhadap anak di dasar atas prinsip-prinsip sebagai berikut :

1. Anak tidak dapat berjuang sendiri.

Anak adalah modal utama kelangsungan hidup Negara, untuk itu Hak- haknya harus dilindungi. Anak tidak dapat melindungi sendiri hak - haknya karena banyak pihak yang mempengaruhi kehidupannya. Negara dan masyarakat berkepentingan untuk mengusahakan perlindungan hak hak anak.

2. Kepentingan terbaik anak.

Agar perlindungan anak diselenggarakan dengan baik, maka harus menganut prinsip bahwa kepentingan terbaik anak harus dipandang sebagai prioritas tertinggi dalam setiap keputusan yang menyangkut anak. Prinsip ini digunakan karena dalam banyak hal anak "korban", disebabkan karena ketidaktahuan anak,karena usia perkembangannya.

3. Ancangan daur kehidupan.

Perlindungan anak mengacu pada pemahaman bahwa perlindungan dimulai dari sejak dini dan terus menerus. Janin dalam kandungan dilindungi dengan pemenuhan gizi. Setelah lahir dibutuhkan adanya ASI dan pelayanan kesehatan primer seperti imunisasi dan lain - lain agar anak terbebas dari penyakit. Pada masa sekolah dibutuhkan keluarga, pendidikan yang

4) http://e-journal.ac.id/7178/1JURNAL.pdf,. 
bermutu. Anak memperoleh kesempatan belajar yang baik, waktu istirahat dan bermain yang cukup. Setelahnya anak akan memasuki usia dewasa maka bertanggung jawab atas segala perbuatannya.

4. Lintas sektoral

Nasib anak tergantung dari banyak faktor, baik secara makro maupun secara mikro, baik yang langsung dan tidak langsung. Perlindungan terhadap anak adalah perjuangan yang membutuhkan sumbangan semua orang disemua tingkatan, tidak hanya keluarga atau anak itu sendiri. ${ }^{5)}$

\section{Hak dan Kewajiban Anak}

Telah disebutkan di atas bahwa anak merupakan karunia dari Tuhan Yang Maha Esa yang harus dijaga karena dalam dirinya melekat harkat, martabat dan hak-hak sebagai manusia yang harus dijunjung tinggi. Berbicara mengenai anak tidak bisa lepas tentang hak dan kewajibannya. Mengenai hal tersebut anak memiliki hak-hak dan kewajiban yang harus dipenuhi dan dilaksanakan berdasarkan Peraturan Perundang undangan.

Tujuan dari perlindungan anak adalah menjamin terpenuhinya hak-hak anak agar dapat hidup, tumbuh, berkembang dan berpartisipasi secara optimal sesuai dengan harkat dan martabat kemanusiaan serta membuat kemanusiaan serta mendapat perlindungan dari diskriminasi, demi terwujudnya anak Indonesia yang berkualitas, berakhlak dan sejahtera. Untuk itu bimbingan, pembinaan dan perlindungan dari orang tua, guru, serta orang dewasa lainnya amat dibutuhkan dalam perkembangannya.

Dalam hukum positif Indonesia, perlindungan hukum terhadap hak anak dapat dijumpai dalam berbagai peraturan perundang-undangan, yakni dalam Keputusan Presiden Nomor 36 Tahun 1990 yang merupakan ratifikasi dari Konvensi PBB tentang Hak-Hak Anak, Undang-Undang Nomor 4 Tahun 1979 tentang Kesejahteraan Anak, Undang-Undang Nomor 23 Tahun 2002 tentang Perlindungan Anak Juncto Undang-Undang Nomor 35 Tahun 2014 Tentang Perubahan Undang-Undang Nomor 23 Tahun 2002 Tentang Perlindungan Anak. Berikut adalah hak-hak anak yaitu :

a. Hak-Hak Anak dalam Keputusan Presiden Nomor 36 Tahun 1990

1. Memperoleh perlindungan dari bentuk diskriminasi dan hukuman

2. Memperoleh perlindungan dan perawatan seperti untuk kesejahteraan dan kesehatan.

3. Tugas Negara untuk menghormati tanggung jawab, hak dan kewajiban orang tua serta keluarga.

4. Anak mempunyai hak untuk menyatakan pendapat sesuai tingkat usia dan perkembangannya $\&$ dipertimbangkan pendapatnya.

5. Anak mempunyai baik hak-hak sipil maupun hak-hak ekonomi, sosial \& budaya

b. Hak-Hak Anak dalam Undang-undang Nomor 4 Tahun 1979 Tentang Kesejahteraan Anak. Dalam Pasal 2 disebutkan Hak Anak yaitu :

1. Anak berhak atas kesejahteraan, perawatan, asuhan dan bimbingan berdasarkan kasih sayang baik dalam keluarganya maupun di dalam asuhan khusus untuk tumbuh dan berkembang dengan wajar.

2. Anak berhak atas pelayanan untuk mengembangkan kemampuan dan kehidupan sosialnya, sesuai dengan kebudayaan dan kepribadian bangsa, untuk menjadi warga negara yang baik dan berguna.

3. Anak berhak atas pemeliharaan dan perlindungan, baik semasa dalam kandungan maupun sesudah dilahirkan.

4. Anak berhak atas perlindungan terhadap lingkungan hidup yang dapat membahayakan atau menghambat pertumbuhan dan perkembangannya dengan wajar.

5) Maidin Gultom, Perilindungan Hukum terhadap anak dan perempuan, Refika Aditama,Bandung 2012, hlm $70-72$ 
c. Hak-Hak Anak dalam Undang-Undang Nomor 35 Tahun 2014 Tentang Perubahan Atas Undang-Undang Nomor 23 Tahun 2002 Tentang Perlindungan Anak

Menurut Undang-Undang Nomor 35 Tahun 2014 tentang perubahan atas UndangUndang Nomor 23 Tahun 2002 tentang Perlindungan Anak. Pasal 1 angka 12, hak anak adalah bagian dari Hak Asasi Manusia yang wajib dijamin, dilindungi, dan dipenuhi oleh Orang Tua, Keluarga, masyarakat, negara, pemerintah, dan pemerintah daerah.

Hak anak adalah bagian dari hak asasi manusia yang wajib dijamin dilindungi, dan dipenuhi oleh orang tua, keluarga, masyarakat, pemerintah, dan Negara. Setiap anak berhak atas perlindungan dari tindak kekerasan secara fisik maupun mental dan diskriminasi serta hak sipil dan kebebasan. Menurut Undang-Undang Nomor 23 Tahun 2002 tentang Perlindungan Anak, hak-hak anak diatur dalam Pasal 4 sampai Pasal 18. Dan pada Pasal 19 telah diatur tentang kewajiban anak. 20 Hak-hak anak dalam proses peradilan pidana merupakan suatu hasil interaksi yang saling terkait dan mempengaruhi dengan yang lainnya. Aspek mental, fisik, sosial, dan ekonomi merupakan faktor yang harus ikut diperhatikan dalam pengembangan hak-hak. Untuk mendapatkan suatu keadilan diperlukan adanya keseimbangan antara hak dan kewajiban. Demikian juga halnya dengan pelaksanaan hak dan kewajiban bagi anak yang menjadi korban dari tindak pidana perlu mendapatkan bantuan dan perlindungan hukum agar tercapai suatu keadilan yang diharapkan.

Kewajiban dan hak adalah suatu pasangan yang sulit terpisahkan antara satu dan lainnya.Kewajiban anak adalah suatu yang harus dilakukan. Kebanyakan hak akan muncul apabila sudah melakukan kewajiban terlebih dahulu. Berdasarkan Undang-Undang Nomor 35 Tahun 2014 Tentang Perubahan Atas Undang-Undang No. 23 Tahun 2002 tentang Perlindungan Anak, terdapat lima kewajiban anak yang harus dilakukan, yaitu:

1. Menghormati orang tua, wali dan guru.

2. Mencintai keluarga, masyarakat dan menyayangi temannya.

3. Mencintai tanah air, bangsa dan negara.

4. Menunaikan ibadah sesuai dengan ajaran agamanya.

5. Melaksanakan etika dan akhlak mulia. $\left.{ }^{6}\right)$

\section{Tinjauan Mengenai Eksploitasi Anak}

\section{Pengertian Eksploitasi Anak}

Berdasarkan Kamus Besar Bahasa Indonesia (KBBI), yang dimaksud dengan eksploitasi adalah pengusahaan, pendayagunaan, pemanfaatan untuk keuntungan sendiri, pengisapan, pemerasan tenaga orang. ${ }^{7)}$

Pengertian eksploitasi anak adalah pemanfaatan anak sebagai objek penghasil uang. Dalam artian kasarnya adalah menganggap anak sebagai mesin mencetak uang yang bisa memenubi berbagai kebutuhan. Contohnya, seorang anak kecil yang cantik dan pintar bernyanyi disuruh orang tuanya untuk manggung kesana kemari guna mendapatkan uang tanpa menghiraukan pendidikan dan kehidupan masa kecil anak tersebut. $\left.{ }^{8}\right)$

Meskipun tidak dijelaskan secara umum mengenai eksploitasi, namun dalam pasal 66 Undang-Undang Nomor 35 Tahun 2014 tentang perubahan atas Undang-Undang Nomor 23 Tahun 2002 Tentang Perlindungan Anak memberikan penjelasan mengenai anak yang dieksploitasi secara ekonomi, yaitu :

6) Angger Sigit Pramukti, Sistem Peradilan Pidana Anak, Yogyakarta, Pustaka Yustisia. Hlm. 15

7) Anne Ahira, Anak Bukan Objek Eksploitasi, http:// AnneAhira.com, Diakses Pada Hari Jumat, 30 Agustus 2018, Pukul 20. 00 WIB.

${ }^{8)}$ Www.pengertianmenurutparaahli.com 
Yang dimaksud dengan Dieksploitasi secara ekonomi adalah tindakan dengan atau tanpa persetujuan anak yang menjadi korban eksploitasi, tetapi tidak terbatas pada pelacuran, kerja atau pelayanan paksa, perbudakan atau praktik serupa perbudakan, penindasan, pemerasan, pemanfaatan fisik, seksual, organ reproduksi, atau secara melawan hukum memindahkan atau mentransplantasi organ dan / atau jaringan tubuh atau memanfaatkan tenaga atau kemampuan anak oleh pihak lain untuk mendapatkan keuntungan materill.

Yang Dimaksud dengan “Dieksploitasi secara seksual” adalah segala bentuk pemanfaatan organ tubuh seksual atau organ tubuh lain dari anak untuk mendapatkan keuntungan, termasuk tetapi tidak terbatas pada semua kegiatan pelacuran.

Dengan demikian dapat di pahami Pengertian eksploitasi terhadap anak jika dilihat secara umum adalah mempekerjakan seorang anak dengan tujuan ingin meraih keuntungan yang sebesar besarnya. Dilihat dari penjelasan diatas, seorang anak mempunyai jaminan perlindungan hukum dari kegiatan eksploitasi ekonomi dan seksual, hal ini dikarenakan seorang anak belum bisa menjaga dirinya sendiri dan bisa berdampak buruk untuk kesehatan fisik maupun moralnya. Maka dari itu, seorang anak berhak mendapatkan perlindungan dari orang tua atau pihak lain yang bertanggung jawab, seperti yang tercantum dalam Pasal 13 Ayat (1) Undang-Undang Nomor 23 Tahun 2002 Sebagaimana telah diubah berdasarkan Undang-Undang Nomor 35 Tahun 2014 Tentang Perubahan Undang-Undang Nomor 23 tahun 2002 Tentang Perlindungan Anak berbunyi :

"Setiap anak selama dalam pengasuhan orang tua, wali, atau pihak lain mana pun yang bertanggung jawab atas pengasuhan, berhak mendapat perlindungan dari perlakuan:
a. diskriminasi;
b. eksploitasi, baik ekonomi maupun seksual;
c. penelantaran;
d. kekejaman, kekerasan, dan penganiayaan;
e. ketidakadilan; dan
f. perlakuan salah lainnya"

\section{Bentuk Bentuk Eksploitasi Terhadap Anak}

Bentuk-bentuk pekerjaan terburuk untuk anak menurut Undang - Undang Nomor 1 Tahun 2000 tentang Pengesahan Konvensi ILO Nomor 182 mengenai pelarangan dan tindakan segera penghapusan bentuk-bentuk pekerjaan terburuk untuk anak adalah :

a. Segala bentuk perbudakan atau praktek sejenis perbudakan seperti penjualan dan perdaganagn anak, kerja ijon (debt bondage) dan penghambatan (serfdom) serta kerja paksa atau wajib kerja, termasuk penggerakan anak secara paksa atau wajib kerja, untuk dimanfaatkan dalam konflik bersenjata.

b. Pemanfaatan, penyediaan atau penawaran anak untuk pelacuran, untuk produksi pornografi, atau untuk pertunjukan - pertunjukan porno.

c. Pemanfaatan penyediaan atau penawaran anak untuk kegiatan terlarang, khususnya untuk produksi dan perdagangan obat - obatan sebagaiamana diatur dalam perjanjian internaional yang relevan.

d. Pekerjaaan yang sifat atau keadaan tempat pekerjaan itu dilakukan dapat membahayakan kesehatan, keselamatan atau moral anak-anak.

Pengertian bentuk- bentuk pekerjaan terburuk untuk anak-anak menurut UndangUndang Nomor 1 Tahun 2000 tersebut di atas di Indonesia secara umum meliputi anak-anak yang dieksploitasi secara fisik maupun ekonomi yang antara lain dalam bentuk :

a. Anak-anak yang dilacurkan.

b. Anak-anak yang bekerja dipertambangan.

c. Anak-anak yang bekerja sebagai penyelam mutiara.

d. Anak-anak yang bekerja di sektor konstruksi.

e. Anak-anak yang bekerja di jermal.

f. Anak-anak yang bekerja sebagai pemulung sampah. 
g. Anak-anak yang dilibatkan dalam produksi dan kegiatan yang menggunakan bahanbahan peledak.

h. Anak-anak yang bekerja di jalan.

i. Anak-anak yang bekerja sebagai pembantu rumah tangga.

j. Anak-anak yang bekerja di perkebunan.

k. Anak-anak yang bekerja pada industri rumah tangga.

I. Anak-anak yang bekerja pada penerbangan, pengolahan dan pengangkutan kayu.

$\mathrm{m}$. Anak-anak yang bekerja pada industri dan jenis kegiatan yang menggunakan bahan kimia yang berbahaya. ${ }^{9}$ )

\section{Pengertian Profesi Artis}

Artis adalah suatu kata dari bahasa Indonesia yang diadaptasi dari bahasa Inggris yaitu "Artist". Sedangkan pengertian Artist kedalam bahasa Indonesia adalah "seniman". Jadi orang - orang yang melakukan seni seperti Penyanyi (olah vokal), Pelukis (menggambar), Akting, Penari, Pewayang dan semua pekerjaan yang berhubungan dengan seni bisa dikatakan sebagai artis. $^{10)}$

Artis cilik adalah sebutan bagi selebritis yang merintis karir di usia kanak-kanak (14 Tahun kebwah). Artis cilik bisa berupa actor, aktris, penyanyi maupun multiprofesi. ${ }^{11)}$

\section{PEMBAHASAN}

\section{Perlindungan Hukum Terhadap Eksploitasi Anak Yang Berprofesi Artis Berdasarkan Undang-Undang Nomor 35 Tahun 2014}

Tujuan Perlindungan anak didasarkan untuk menjamin terpenuhi hak hak anak agar dapat hidup, tumbuh, berkembang dan berpartisipasi secara optimal sesuai dengan harkat dan martabat kemanusiaan, serta mendapat perlindungan dari kekerasan dan diskriminasi. Karena anak memiliki keterbatasan dalam memahami dan melindungi diri dari berbagai pengaruh sistem yang ada, sehingga agar kelak anak mampu bertanggung jawab di kehidupan berbangsa dan bernegara, setiap anak perlu mendapat kesempatan yang seluas-luasnya untuk tumbuh, dan berkembang secara optimal, baik fisik, mental, sosial. Anak-anak mempunyai hak untuk berisitirahat dan memanfaatkan waktu luang, bergaul dengan anak sebaya, berrekreasi berkreasi sesuai dengan minat, bakat dan tingkat kecerdasannya demi pengembangan diri. Maka dalam hal ini setiap anak yang dalam pengasuhan orang tua, wali, atau pihak lain manapun yang bertanggung jawab atas pengasuhan, tidak boleh mendapatkan perlakuan diskriminasi kekerasan, dan eksploitasi baik secara ekonomi maupun secara seksual. Termasuk dalam hal ini adalah kategori anak yang telah bekerja atau pekerja anak. Pekerja anak yang melaksanakan pekerjaan dalam suatu hubungan kerja memiliki hak untuk mendapatkan perlindungan sebagaimana anak-anak pada umumnya.

Dalam kedua kasus ini jelas bahwa anak-anak tersebut dimanfaatkan oleh orang tua menjadi tulang punggung keluarga yang dalam kondisi Misca Fortuna masih berusia 8 tahun dalam menjalani pekerjaannya sebagai artis cilik dengan berperan di salah satu sinetron kejar tayang dimana Misca Fortuna bekerja hingga larut. menurut Undang-Undang Nomor 13 Tahun 2003 tentang Ketenagakerjaan anak dalam usia tersebut dilarang untuk bekerja lebih dari 3 (tiga) jam dan hal ini dapat menyebabkan hak-hak Misca sebagai anak tidak terpenuhi. Pada usia tersebut anak membutuhkan bimbingan orang tua untuk pertumbuhan fisik dan mental anak agar anak dapat tumbuh, berkembang dengan baik. sementara Tegar Septian di eksploitasi secara seksual oleh pihak lain dimanfaatkan demi memenuhi nafsu semata, karena seorang manager Tegar ini tergolong orang pedofil atau penyimpangan seksual terhadap anak kecil tanpa mempertimbangkan rasa kepatutan, keadilan serta konpensasi kesejahteraan

\footnotetext{
9) Abdussalam dkk, Hukum Perlindungan Anak (Jakarta: PTIK, 2016), hlm. 112-114

${ }^{10)} \mathrm{https}: / /$ id.wikipedia.org/wiki/Seniman

11) Ibid
} 
terhadap anak. Tindakan ini telah memenuhi unsur bahwa penyanyi cilik Tegar ini telah mengalami tindakan eksploitasi secara seksual dari pihak manager.

Menurut Penulis dari kedua kasus tesebut memiliki kemiripan dengan peristiwa hukum yang dialami, unsur-unsur rumusan Pasal 13 ayat (1) huruf c jo Pasal 76 I memenuhi unsur untuk di terapkan kepada para pelaku yang melanggar hak-hak anak dan telah secara sengaja ataupun tidak sengaja, secara sadar atau tidak sadar telah melakukan eksploitasi. Para pelaku telah memenuhi unsur-unsur tindak pidana yaitu adanya unsur kesalahan. Kesalahan dalam hukum pidana pada umumnya dijatuhkan kepada seseorang melakukan perbuatan yang dilarang, dengan dikehendaki dan diketahui (willens en wettens). para pelaku memenuhi unsur subjektif unsur objektif syarat pemidanaan yaitu adanya sifat perbuatan melawan hukum (wederechtelick) yang mana kedua orang tua Misca Fortuna dengan sengaja mempekerjakan anaknya tidak sesuai dengan peraturan perundang-undangan yang berlaku mengenai batasan usia kerja anak, durasi kerja melebihi ketentuan, kemudian waktu yang mengganggu aktivitas pendidikan anak. selain itu menjadikan Misca Fortuna sebagai tulang punggung keluarga. Pada kasus Tegar Septian adanya unsur kesengajaan (dolus) dari pihak lain dalam hal ini manager dengan cara memanfaatkan secara sewenang-wenang tanpa mempertimbangkan rasa kepatutan, keadilan serta kesejahteraan dengan melakukan perbuatan tidak senonoh, hal tersebut bisa dikatakan eksploitasi secara seksual terhadap anak. Disini tampak jelas bahwa anak tersebut diperlakukan secara sewenang-wenang dan telah melakukan perbuatan yang tidak senonoh bahkan cenderung ke arah perbuatan pornografi dan menelanjangi anak. Perbuatan ini sangat jelas telah memenuhi unsur eksploitasi seksual serta sifat perbuatan melawan hukum (wederechtelick) yang ada pada ketentuan peraturan perundang- undangan tersebut. Pelanggaran terhadap pasal tersebut adalah diatur dalam Pasal 88 yang menyebutkan bahwa setiap orang yang telah melakukan tindakan eksploitasi kepada anak baik eksploitasi ekonomi ataupun eksploitasi seksual akan dikenakan pidana penjara paling lama 10 (sepuluh) tahun dan/atau denda paling banyak Rp.200.000.000,00 (dua ratus juta rupiah) yang kemudian pada Pasal 13 ayat (2) huruf b Undang-Undang Nomor 23 Tahun 2002 tentang Perlindungan Anak juga mengatur tentang pemberatan hukuman kepada pihak orang tua, wali atau pengasuh anak apabila melakukan segala bentuk eksploitasi terhadap anak.

Perlindungan terhadap anak tidak dapat dipisahkan dari peran Negara, pemerintah baik pusat maupun daerah, masyarakat, keluarga, orang tua. Tidak ditaatinya peraturan perlindungan anak oleh orang tua ataupun masyarakat lainnya sebenarnya tidak perlu terjadi apabila pemerintah, dalam hal ini dinas daerah yang menangani ketenagakerjaan khususnya pegawai pengawas ketenagakerjaan dapat menjalankan fungsinya sebagai mana fungsinya, yaitu benar-benar melakukan pengawasan terhadap pelaksanaan dan melakukan penindakan sesuai peraturan yang berlaku. Sebagai satu system perlindungan hukum pegawai ketenagakerjaan melakukan tindakan mengawasi pelaksanaan peraturan hukum mengenai ketenagakerjaan penggunaan ketenagakerjaan anak serta masalah-masalah anak yang terkait.

\section{Upaya Penanggulangan Pemerintah Terhadap Anak yang Berprofesi Artis Dari Tindakan Eksploitasi}

Berdasarkan hasil yang telah di uraikan, menurut analisa penulis upaya penanggulangan pemerintah untuk melindungi anak di negara Indonesia sudah dilakukan dengan adanya suatu badan perlindungan anak Indonesia yakni KPAI. Namun masih terdapat kelemahan yang mana KPAI belum optimal dalam melakukan pengawasan terhadap anak anak yang bekerja sebagai profesi artis sehingga dapat dimanfaatkan oleh pihak-pihak yang berkepentingan, misalnya alasan orang tua untuk mengembangkan bakat anak yang karena hubungan orang tua dan anak ini tidak ada batasan yang memebedakan antara pengembangan minat dan bakat anak dengan eksploitasi terhadap anak. Anak yang ketika ditampilkan di dunia hiburan seharusnya tidak mengurangi hak-hak anak sebagaimana tertuang dalam Undang-Undang Nomor 23 Tahun 2002 tentang Perlindungan Anak yang telah dirubah dengan Undang-Undang Nomor 35 Tahun 2014. 
Hukum kebiasaan di masyarakat yang menempatkan orang tua "berhak" melakukan apa saja pada anaknya meski tanpa disadari merugikan anak, memberi kontribusi terhadap maraknya akan pelanggaran hak-hak anak. Kasus anak-anak yang bekerja pada sektor informal yang diakui orang tua sebagai tradisi, jelas akan menjadi biasa manakala orang tua "mempekerjakan" anak tanpa memperhatikan pendidikan anaknya.

Upaya-upaya yang dapat dilakukan Pemerintah untuk menanggulangi permasalahan anak dapat dilakukan dengan 2 (dua) cara yakni, perlindungan, dan pemberdayaan.

Pertama; Perlindungan, muncul berdasarkan pandangan bahwa anak sebagai individu mempunyai hak untuk bekerja. Oleh karenanya hak-haknya sebagai pekerja harus dijamin melalui peraturan ketenagakerjaan sebagaimana yang berlaku bagi pekerja dewasa, sehingga terhindar dari tindak penyalahgunaan dan eksploitasi. Karena bekerja adalah bagian dari hak asasi anak yang paling dasar, meskipun masih anak-anak hukum harus dapat menjamin terwujudnya hak anak yang paling asasi untuk mendapatkan pekerjaan dan oleh karenanya juga mendapatkan penghidupan yang layak bagi kemanusiaan. Masa depan anak tidak lagi ditentukan oleh kekuatan orang tua, keluarga, masyarakat, apalagi negara. Tetapi sebaliknya orang tua, keluarga, masyarakat dan negara, mempunyai kewajiban untuk menjamin terwujudnya hak anak yang paling asasi yakni mendapatkan pekerjaan dan penghidupan yang layak bagi kemanusiaan.

Anak yang tereksploitasi secara ekonomi dan seksual mendapatkan perlindungan khusus oleh pemerintah dan masyarakat yang dilakukan melalui :

a. Penyebarluasan dan/atau sosialisasi lebih lanjut mengenai ketentuan peraturan perundang-undangan yang berkaitan dengan perlindungan anak yang dieksploitasi secara ekonomi dan/atau seksual;

b. Pemantauan, pelaporan, dan pemberian sanksi. Pemerintah dalam hal upaya menaggulangi permasalahan anak melalui dinas terkait dimulai dari daerahdaerah melakukan pengawasan secara baik dan berlanjut, kemudian mengenai pemberian sanksi terhadap pelaku terkait harus lebih tegas.

c. Pelibatan berbagai instansi pemerintah, perusahaan, serikat pekerja, lembaga swadaya masyarakat dan juga masyarakat dalam upaya menaggulangi tindakan eksploitasi terhadap anak secara ekonomi dan/atau seksual.

Kedua; Pemberdayaan, dilakukan terhadap pekerja anak agar mendapatkan pengakuan terhadap hak-haknya dengan memberikan keterampilan sesuai dengan kebutuhannya.

\section{PENUTUP}

\section{Kesimpulan}

1. Peraturan perlindungan anak pada dasarnya sudah sangat jelas dan diatur dalam perundang-undangan dan mengenai peran daripada orang tua terhadap anak anak. Namun pada kenyataannya perlindungan hukum terhadap anak profesi artis sangat rendah pada aspek atau tataran penerapannya dikarenakan hukum kebiasaan dimana peran orang tua dapat melakukan apapun terhadap anak sehingga anak-anak menjadi korban eksploitasi dari orang dewasa baik itu oleh orang tua, wali, pihak pengusaha. Dan seharusnya Anak yang dalam pengasuhan orang tua, wali, atau pihak lain manapun bertanggung jawab atas pengasuhan, tidak boleh mendapatkan perlakuan diskriminasi ,kekerasan, dan eksploitasi baik secara ekonomi maupun secara seksual.

2. Perlindungan terhadap kesejahteraan anak merupakan bagian dari tanggung jawab orang tua dan kepedulian masyarakat. Tanpa partisipasi masyarakat, pendekatan legal formal saja ternyata tidak cukup efektif dalam melindungi anak. Komunitas lokal (Government Organization dan Non Government Oragnization ) memiliki peran penting dalam merancang kebijakan dan program aksi perlindungan anak. Kebijakan dan program aksi perlindungan anak berperan sebagai piranti dalam melindungi anak dari tindakan 
kekerasan dan eksploitasi. Upaya Penanggulangan yang dapat dilakukan oleh pemerintah terhadap permasalahan eksploitasi anak berprofesi artis harus dilakukan oleh berbagai pihak terutama orang tua. Pemertintah Negara Republik Indonesia tidak cukup hanya menggunakan sarana Represif (penindakan) sehingga harus memerlukan adanya korban terlebih dahulu. Karena persoalan anak tidak bisa diselesaikan oleh salah satu pihak, melainkan harus secara bersama-sama antara Pemerintah, orang tua dan masyarakat.

\section{Saran}

1. Pengawasan oleh Pemerintah terhadap para pengusaha untuk melindungi anak anak yang bekerja khususnya anak yang berprofesi sebagi artis yang telah dibahas penulis, pengawasan dimulai melalui perangkat di daerah yakni melalui dinas ketenagakerjaan dan lembaga perlindungan anak yaitu komisi perlindungan anak Indonesia.

2. Anak yang tereksploitasi secara ekonomi dan seksual mendapatkan perlindungan khusus oleh pemerintah dan masyarakat yang dilakukan melalui penyebarluasan dan/atau sosialisasi ketentuan peraturan perundang-undangan yang berkaitan dengan perlindungan anak yang dieksploitasi secara ekonomi dan/atau seksual, Pemantauan, pelaporan, dan pemberian sanksi; Pelibatan berbagai instansi pemerintah, perusahaan, serikat pekerja, lembaga swadaya masyarakat dan juga masyarakat dalam penghapusan eksploitasi terhadap anak secara ekonomi dan/atau seksual.

\section{DAFTAR PUSTAKA}

Abu Huraerah, Kekerasan Terhadap Anak, Nuansa, Bandung 2006, Abdussalam dkk, Hukum Perlindungan Anak (Jakarta: PTIK, 2016), Angger Sigit Pramukti, Sistem Peradilan Pidana Anak, Yogyakarta, Pustaka Yustisia.

Maidin Gultom, Perilindungan Hukum terhadap anak dan perempuan, Refika Aditama,Bandung 2012

R.A. Koesnan, Susunan Pidana dalam Negara Sosialis Indonesia, (Bandung :Sumur, 2005)

Anne Ahira, Anak Bukan Objek Eksploitasi, http:// AnneAhira.com, Diakses Pada Hari Jumat, 30 Agustus 2018, Pukul 20. 00 WIB

http://free.makalah.blogspot.com/2010/07perlindungan-anak-menurut-uu-no.html?m=1

http://e-journal.ac.id/7178/1JURNAL.pdf,.

www.pengertianmenurutparaahli.com

https://id.wikipedia.org/wiki/Seniman 